\title{
IMPACT OF MOISTURE AND SPEED OF THRESHERS ON EFFICIENCY OF CRUSHING OF LUPINE SEEDS
}

Sławomir Gawłowski ${ }^{a}$, Ryszard Kulig ${ }^{\text {b* }}$, Grzegorz Łysiak ${ }^{\mathrm{c}}$, Al Aridhee Jawad Kadhim ${ }^{\mathrm{d}}$, Zdybel Adam ${ }^{\mathrm{e}}$, Paweł Hyła ${ }^{\mathrm{f}}$

a Department of Food Engineering and Machines, University of Life Sciences in Lublin, Poland, e-mail: slawomir.gawlowski@up.lublin.pl

b Department of Food Engineering and Machines, University of Life Sciences in Lublin, Poland, e-mail: ryszard.kulig@up.lublin.pl; ORCID 0000-0003-0994-8140

${ }^{c}$ Department of Food Engineering and Machines, University of Life Sciences in Lublin, Poland, e-mail: grzegorz.lysiak@up.lublin.pl; ORCID 0000-0002-4942-3050

d College of Agriculture, Al Muthanna University, Al Muthanna 66001, Iraq, e-mail: jawadaridhee@gmail.com

e Department of Food Engineering and Machines, University of Life Sciences in Lublin, Poland, e-mail: adam.zdybel@up.lublin.pl

${ }^{\mathrm{f}}$ Department of Food Engineering and Machines, University of Life Sciences in Lublin, Poland, e-mail: icetee@interia.pl

*Corresponding author: e-mail: ryszard.kulig@up.lublin.pl

\begin{tabular}{|c|c|}
\hline ARTICLE INFO & ABSTRACT \\
\hline $\begin{array}{l}\text { Article history: } \\
\text { Received: April } 2020 \\
\text { Received in the revised form: } \\
\text { May } 2020 \\
\text { Accepted: May } 2020\end{array}$ & $\begin{array}{l}\text { The objective of the paper was to determine the impact of moisture and } \\
\text { rotational speed of threshers on the process of crushing of lupine seeds. } \\
\text { Raw material was led to four levels of moisture from } 8 \text { to } 14 \% \text { every } \\
2 \% \text {. The studies were carried out on the laboratory hammer mill with } \\
\text { the use of variable speeds of mill hammers within } 5500-7000 \mathrm{rot} \cdot \mathrm{min}^{-1} \text {. }\end{array}$ \\
\hline $\begin{array}{l}\text { Key words: } \\
\text { lupine, } \\
\text { crushing, } \\
\text { moisture, } \\
\text { speed of hammers, } \\
\text { hammer mill }\end{array}$ & $\begin{array}{l}\text { The studies that were carried out proved significant relations }(\mathrm{p}<0.05) \\
\text { between the analysed process variables and energy consumption and } \\
\text { susceptibility of seeds to crushing. It was stated that along with the in- } \\
\text { crease of the rotational speed, a reduction in the drop of the average } \\
\text { dimension of particles of mill takes place. Along with the increase of } \\
\text { moisture of lupine from } 8 \text { to } 14 \% \text { a unit energy of crushing increases } \\
\text { on average by approx. } 83 \% \text {. It was proved that the susceptibility ratio } \\
\text { of seeds to crushing increases along with the increase of raw material } \\
\text { moisture. Such relations were determined for all investigated rotational } \\
\text { speeds of hammers. }\end{array}$ \\
\hline
\end{tabular}

\section{List of markings:}

$\mathrm{d}_{\mathrm{m}} \quad$ - average size of particles, $(\mathrm{mm})$

$E_{f} \quad$ rate of seeds susceptibility to crushing, $\left(\mathrm{J} \cdot \mathrm{m}^{-2}\right)$

$\mathrm{E}_{\mathrm{r}} \quad$ - unit energy consumption of crushing $\mathrm{g}^{-1},\left(\mathrm{~J} \cdot \mathrm{g}^{-1}\right)$

$\mathrm{E}_{\mathrm{roz}}$ - total energy of crushing, $(\mathrm{J})$

$\mathrm{h}_{\mathrm{i}} \quad$ - average value of the class range, $(\mathrm{mm})$

$\mathrm{m}_{\mathrm{r}} \quad-$ mass of the crushed sample, $(\mathrm{g})$ 


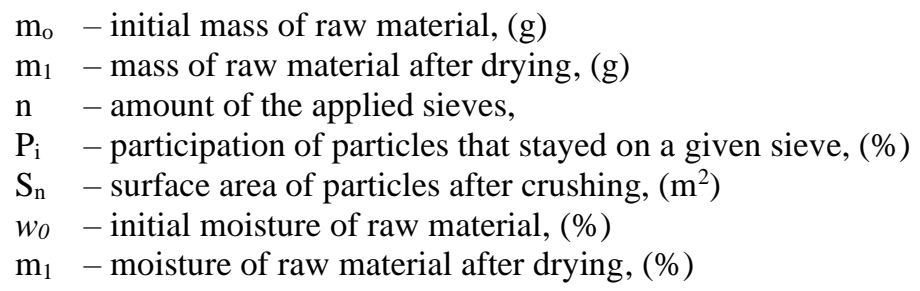

\section{Introduction}

Lupine seeds due to health and nutritive values may be used both in the human and livestock diet. "Sweet" lupine in this context is of particular meaning, considerably devoid of alkaloids which cause that seeds are untasty and sometimes even toxic. Some lupine cultivars subjected to a suitable treatment give products with properties that are remarkably similar to soya products, especially if it is related to composition and assimilability (Olkowski, 2018).

Another significant argument for the use of lupine as a crop is its natural ability to leave substantial quantities of nitrogen compounds in soil, which influences consumption of mineral fertilizers. Moreover, lupine plays a significant role due to the ability to release limited phosphorus, unavailable for other plant species which simultaneously guarantees better conditions for successive plants growth, mainly grains (Roszak, 1999; Ma et al., 2019).

Lupine is perceived as a precious functional element of grain, fruit, dairy and meat products (Bartkiene et al., 2016). Its addition may result in both supplementation of grain protein with deficient lysine as well as introduction of oligosaccharides - compounds that are significant in counteracting diseases of a digestive system (Cruz-Chamorro et al, 2019). It is also used as an additive to bread, which causes the increase of the product shelf life and raises water absorption volume of bread and shortens time of the dough growth (Wandersleben et al., 2018). Moreover, proteins which occur in lupine seeds have properties that reduce the level of cholesterol in the system (López and Goldner, 2015).

In animal feeding, lupine may be a valuable source of protein in fodders for pigs, ruminants, and poultry (Volek et al., 2018; Zduńczyk et al., 2019). For some age groups of animals its admissible content may reach as much as $15 \%$ of weight constituting thus a precious substitute of soya meal (Grudniewska, 1998; Lamp et al., 2015). A technological process of fodder production with its use requires many treatments such as hulling, conditioning and fragmentation (Grochowicz and Andrejko, 1998; Andrejko and Grochowicz, 1999).

Efficiency of production processes in an agri-food industry considerably depends on its proper fragmentation of processed raw material (Kulig and Laskowski, 2002). Crushing is required both due to the increase of the digestion rate as well as to the proper course of technological processes of their refinement (Ball et al., 2015; Gimenoa et al., 2015). It is known that crushing of plant raw materials is related to high energy inputs (Laskowski and Lysiak, 1999; Laskowski et al., 2005; Mayer-Laigle et al., 2018a). In case of granular materials, this process is the most often carried out with the use of hammer mills (Mayer-Laigle et al., 2018b).

Taking the above into consideration, the aim of this paper is to investigate the impact of the moisture degree and rotational speed of mills on the course of the sweet lupine seed 
Impact of moisture...

crushing. These factors (next to a diameter of openings on hammer sieves) mainly decide on the course of the process and degree of crushing and incurred energy inputs.

\section{Materials and Methods}

Th studies on the crushing process were performed on the laboratory hammer mill POLYMIX -Micro - Hammermill MFC. The hammer mill cooperated directly with a computer measuring system of active power single phase. Particular characteristics of the measurement stand were presented in the paper by Laskowski and Łysiak (1999).

A research material consisted of narrow leaf lupine of Kurant cultivar. Raw material was dried according to PN-91/A-74010 to obtain a complex degree of moisture i.e. 8,10,12 and $14 \%( \pm 0.2 \%)$. Required moisture of raw material was determined based on the pattern on the variability of mass in time, according to the following relation (Pabis et al., 1998):

$$
m_{1}=m_{0}\left(\frac{100-w_{0}}{100-w_{1}}\right) \quad(\mathrm{g})
$$

Then, the prepared seeds were subjected to crushing with the use of a sieve with a diameter of opening of $2 \mathrm{~mm}$. During the process, four values of hammer mill speed were applied i.e. $5500,6000,6500$ and $7000 \mathrm{rot} \cdot \mathrm{min}^{-1}$. The measurements were made in five iterations for each speed and seed moisture.

For crushed samples of lupine seeds a size distribution composition was determined according to the Polish standard (PN-89/R-64798) which allowed determination of an average size of particles according to the formula (Branland, 1997):

$$
d_{m}=\frac{\sum_{i=1}^{n} h_{i} P_{i}}{100}(\mathrm{~mm})
$$

Unit energy inputs of crushing $E_{r}$ were determined from the formula:

$$
E_{r}=\frac{E_{r o z}}{m_{r}} \quad\left(\mathrm{~J} \cdot \mathrm{g}^{-1}\right)
$$

On the other hand, the index of susceptibility to crushing $E_{f}$ was determined as a ratio of the total energy collected during crushing and surface of particles after crushing (Posner 1991):

$$
E_{f}=\frac{E_{r o z}}{S_{n}} \quad\left(\mathrm{~J} \cdot \mathrm{m}^{-2}\right)
$$

Measurement results were subjected to statistical analysis with the use of STATISTICA program. The analysis covered determination of mean values, errors, and standard deviations. Moreover, a single analysis of variance was carried out and the significance of differences between the mean values was determined with the use of Tulkey's test. It guarantees, to a considerable extent, maintenance of an error of I type and the assumed level of significance when many simultaneous comparisons are carried out. Moreover, relations in the form of regression equations were determined. All statistical analyses were made with an assumed level of significance of $\alpha=0.05$. 


\section{Results and Discussion}

The obtained research results proved that both moisture as well as speed of hammer mills significantly affect the parameters of the process of crushing of lupine seeds. In table 1-3 results of analysis of variance were presented while in table 4 regression equations that describe the obtained relations. Statistical analysis proved significant differences in values of the average size of particles $d_{m}$ (tab. 1).

Table 1.

Analysis of variance for mean size of particles $d_{m}(\mathrm{~mm})$

\begin{tabular}{|c|c|c|c|c|c|c|}
\hline $\begin{array}{l}\text { Parameters of } \\
\text { analysis of vari- } \\
\text { ance }\end{array}$ & $\begin{array}{c}\text { Hammers } \\
\text { speed } \\
\left(\operatorname{rot} \cdot \min ^{-1}\right)\end{array}$ & $\mathrm{SS} \cdot 10^{4}$ & df & $\mathrm{MS} \cdot 10^{4}$ & $\mathrm{~F}-4$ & $\mathrm{p}$ \\
\hline Absolute term & & 0.06 & 1 & 0.06 & 2.31 & 0.000 \\
\hline Moisture & 7000 & 0.00 & 3 & 0.00 & 0.00 & 0.009 \\
\hline Standard error & & 0.00 & 16 & 0.00 & & \\
\hline Absolute term & & 0.07 & 1 & 0.07 & 2.66 & 0.000 \\
\hline Moisture & 6500 & 0.00 & 3 & 0.00 & 0.00 & 0.001 \\
\hline Standard error & & 0.00 & 16 & 0.00 & & \\
\hline Absolute term & & 0.06 & 1 & 0.06 & 2.20 & 0.000 \\
\hline Moisture & 6000 & 0.00 & 2 & 0.00 & 0.00 & 0.033 \\
\hline Standard error & & 0.00 & 12 & 0.00 & & \\
\hline Absolute term & & 0.04 & 1 & 0.04 & 1.61 & 0.000 \\
\hline Moisture & 5500 & 0.00 & 1 & 0.00 & 0.00 & 0.017 \\
\hline Standard error & & 0.00 & 8 & 0.00 & & \\
\hline
\end{tabular}

When this parameter is analysed it should be emphasised that it more depends on the speed of hammers than on the moisture of raw material. The increase of hammers speed caused reduction of the parameter $d_{m}$ value. Such relations were found referred to all investigated moisture of raw material. It may prove a prevailing role of technical and technological parameters of a hammer mill in shaping the grain size distribution composition of the raw material after crushing which was also proved by Kalwaj (2010) and Bochat and Zastempowski (2019). The value of the mean size of particles was presented in figure 1.

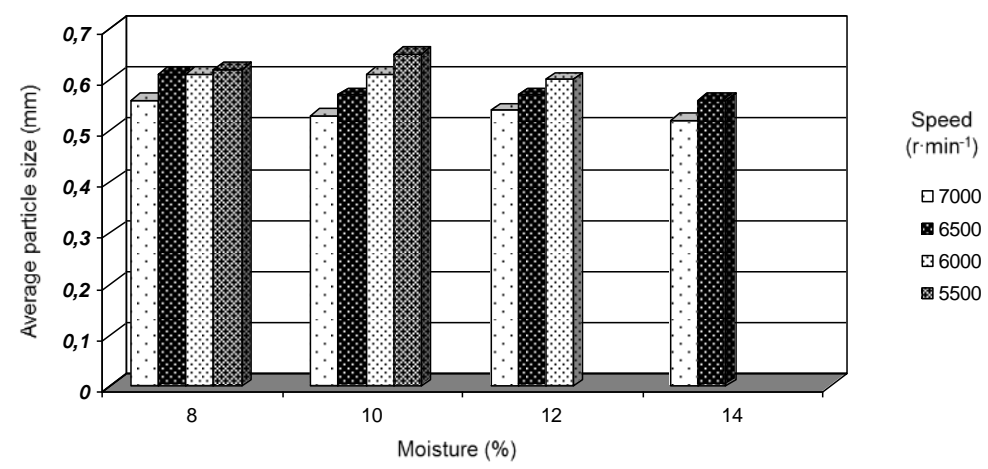

Figure 1. Mean size of particles $d_{m}$ for particular moisture of lupine seeds and speed of hammer mills 
Impact of moisture...

For the set conditions of research (application of a sieve with a diameter of openings of $2 \mathrm{~mm}$ ), in case of raw material with the moisture of $12 \%$ and the use of speed of 5500 rot. $\min ^{-1}$ we were not able to carry out an impact decohesion. The same situation occurred also for a raw material with the moisture of $14 \%$ and the use of speed of 5500 and 6000 $\operatorname{rot} \cdot \mathrm{min}^{-1}$. In all these cases material was not sieved through sieve meshes. Moreover, an attempt was made to crush lupine seeds with the moisture of $16 \%$. However, for such moisture, the crushing process did not take place at any assumed value of the hammers speed.

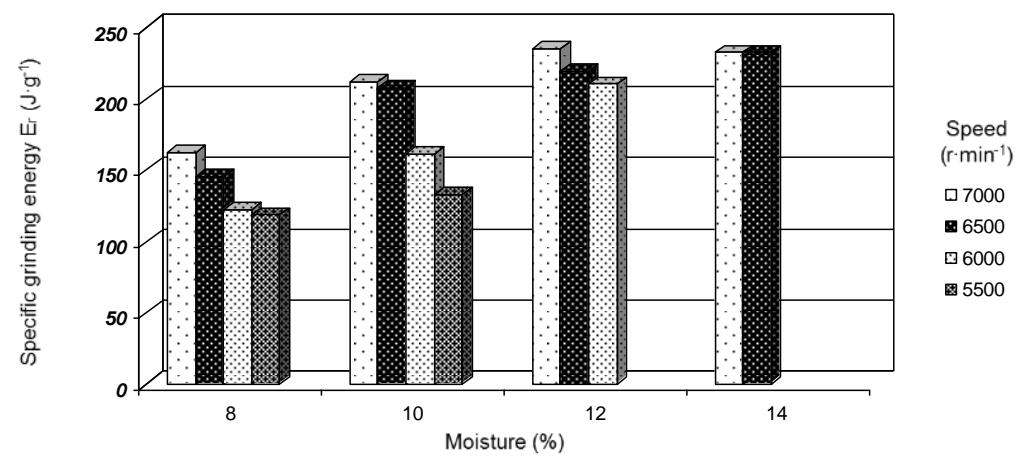

Figure 2. Unit energy of crushing E for particular moisture of lupine seeds and speed of hammer mills

Table 2.

Analysis of variance for unit inputs of energy for crushing $E_{r}\left(J \cdot g^{-1}\right)$

\begin{tabular}{lcccccc}
\hline $\begin{array}{l}\text { Parameters of } \\
\text { analysis of vari- } \\
\text { ance }\end{array}$ & $\begin{array}{c}\text { Hammers } \\
\text { speed } \\
\left(\text { rot } \text { min }^{-1} \text { ) }\right.\end{array}$ & SS & df & MS & F $\cdot 10^{2}$ & $\mathrm{p}$ \\
\hline Absolute term & & 3.42 & 1 & 3.42 & 800.74 & 0.000 \\
Moisture & 7000 & 0.06 & 3 & 0.02 & 4.35 & 0.000 \\
Standard error & & 0.00 & 16 & 0.00 & & \\
Absolute term & 6500 & 0.10 & 1 & 2.82 & 1481.11 & 0.000 \\
Moisture & & 0.00 & 16 & 0.03 & 17.50 & 0.000 \\
Standard error & & 2.13 & 1 & 0.00 & & \\
Absolute term & 6000 & 0.14 & 2 & 0.07 & 677.49 & 0.000 \\
Moisture & & 0.00 & 12 & 0.00 & 21.84 & 0.000 \\
Standard error & 5500 & 0.63 & 1 & 0.63 & 440.61 & 0.000 \\
Absolute term & 0.00 & 1 & 0.00 & 1.47 & 0.000 \\
Moisture & & 0.00 & 8 & 0.00 & & \\
Standard error & & & & & & \\
\hline
\end{tabular}

The unit energy of crushing of lupine seeds with a varied moisture was from $118,706 \mathrm{~J} \cdot \mathrm{g}^{-1}$ (for the lowest rotational speed) to $234,842 \mathrm{~J} \cdot \mathrm{g}^{-1}$ (for the highest speed of hammers). The obtained results were presented in figure 2 . Whereas in table 2 results obtained from the analysis of significance between the average values of parameter $E_{r}$ were presented. The 
value of the parameter increased along with the increase of seed moisture and hammers' speed. A similar trend of energy consumption changes were proved also by other researchers on the example of grain seeds crushing (Dziki, 2008, Marks, 2010).

Also in case of the seed susceptibility rate to crushing, a single dimensional test of significance of variance proved that there are significant differences in the mean values of this parameter both referred to changes in seed moisture as well as hammers; speed (table 3). When analysing the value of $E_{f}$ rate, it was observed that the increase of moisture caused the increase of this parameter. The highest value of the susceptibility ratio to crushing was proved at the moisture of $14 \%$ and speed of $6500 \mathrm{rot} \cdot \mathrm{min}^{-1},\left(14.50 \mathrm{~kJ} \cdot \mathrm{m}^{-2}\right)$. Whereas the lowest value $\left(2.14 \mathrm{~kJ} \cdot \mathrm{m}^{-2}\right)$ was obtained at the speed of $5500 \mathrm{rot} \cdot \mathrm{min}^{-1}$ and moisture of $8 \%$. Figure 3 presents the relations between the susceptibility ratio and moisture for four values of rotational speed.

Table 3 .

Analysis of variance for susceptibility index of seeds to crushing $E_{f}\left(J \cdot m^{-2}\right)$

\begin{tabular}{lcccccc}
\hline $\begin{array}{l}\text { Parameters of } \\
\text { analysis of vari- } \\
\text { ance }\end{array}$ & $\begin{array}{c}\text { Hammers } \\
\text { speed } \\
\left(\mathrm{rot} \cdot \mathrm{min}^{-1}\right)\end{array}$ & $\mathrm{SS} \cdot 10^{2}$ & $\mathrm{df}$ & $\mathrm{MS} \cdot 10^{2}$ & $\mathrm{~F} \cdot 10^{2}$ & $\mathrm{p}$ \\
\hline Absolute term & 7000 & 35.84 & 1 & 35.83 & 30.86 & 0.000 \\
Moisture & 0.40 & 3 & 0.13 & 0.11 & 0.000 \\
Standard error & & 0.19 & 16 & 0.01 & & \\
Absolute term & 6500 & 0.09 & 3 & 0.05 & 0.26 & 0.000 \\
Moisture & & 0.01 & 16 & 0.01 & & \\
Standard error & 6000 & 15.61 & 1 & 15.61 & 22.33 & 0.000 \\
Absolute term & 1.97 & 2 & 0.99 & 1.41 & 0.000 \\
Moisture & & 0.08 & 12 & 0.01 & & \\
Standard error & 5500 & 9.36 & 1 & 9.36 & 15.10 & 0.000 \\
Absolute term & 0.06 & 1 & 0.06 & 0.10 & 0.013 \\
Moisture & & & & & & \\
\hline
\end{tabular}

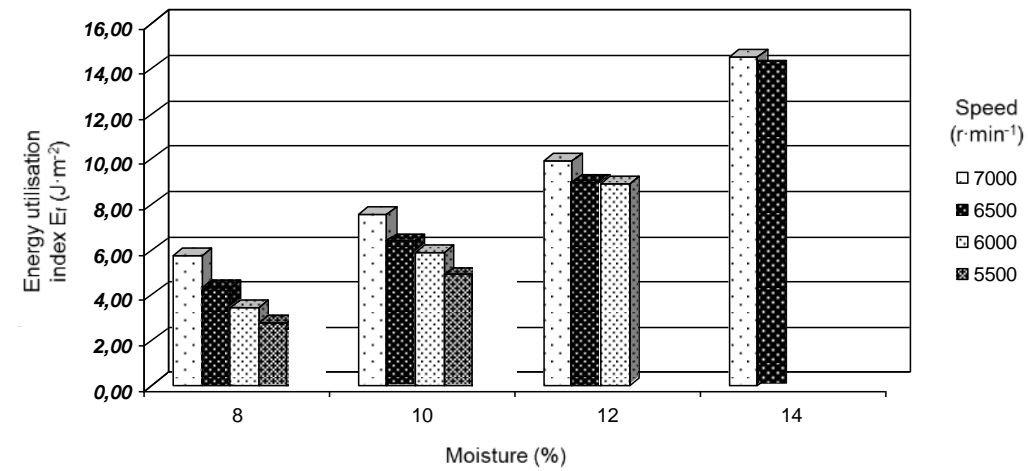

Figure 3. Ration of seeds susceptibility to crushing for particular moisture of lupine seeds and hammers speed 
Impact of moisture...

Regression equations that describe the relation of the investigated parameters of the process to moisture of raw material and rotational speed of hammers were set in table 4 . The obtained data show that the obtained relations may be described with linear and square models. The determined values of $\mathrm{R}^{2}$ coefficient show that the moisture of lupine explains over $94 \%$ of variability within the energy consumption of the crushing process. This happens in case of all investigated rotational speeds of hammers. Whereas the value of $E_{f}$ index is explained on average in $70 \%$ with a variability of raw material moisture.

Table 4.

List of regression equations and value of determination ratio that determine the relation between the parameters of the process of crushing of lupine for various hammer speeds

\begin{tabular}{|c|c|c|c|}
\hline Investigated property & $\begin{array}{c}\text { Hammer } \\
\text { speed } \\
\text { (rot.min }{ }^{-1} \text { ) }\end{array}$ & Equation & $\mathrm{R}^{2}$ \\
\hline Unit energy inputs on crushing $E_{r}\left(J \cdot g^{-1}\right)$ & & $E_{r}=-2.279 w_{z}^{2}+60.98 w_{z}-176.7$ & 0.948 \\
\hline $\begin{array}{l}\text { Index of susceptibility of seeds to crush- } \\
\text { ing } E_{f}\left(\mathrm{~J} \cdot \mathrm{m}^{-1}\right)\end{array}$ & & $\mathrm{E}_{\mathrm{f}}=0.574 \mathrm{w}_{\mathrm{z}}+7.067$ & 0.564 \\
\hline Unit energy inputs on crushing $E_{r}\left(J \cdot g^{-1}\right)$ & & $E_{r}=0.702 w_{z}^{2}+99.10$ & 0.960 \\
\hline $\begin{array}{l}\text { Index of susceptibility of seeds to crush- } \\
\text { ing } E_{f}\left(\mathrm{~J} \cdot \mathrm{m}^{-1}\right)\end{array}$ & 6500 & $\mathrm{E}_{\mathrm{f}}=0.041 \mathrm{wz}_{\mathrm{z}}^{2}+7.766$ & 0.768 \\
\hline Unit energy inputs on crushing $E_{r}\left(J \cdot g^{-1}\right)$ & & $\mathrm{E}_{\mathrm{r}}=-7.274 \mathrm{w}_{\mathrm{z}}^{2}+173.5 \mathrm{w}_{\mathrm{z}}-800.2$ & 0.997 \\
\hline $\begin{array}{l}\text { Index of susceptibility of seeds to crush- } \\
\text { ing } E_{f}\left(\mathrm{~J} \cdot \mathrm{m}^{-1}\right)\end{array}$ & 6000 & $E_{f}=-0.568 w_{z}^{2}+13.36 w_{z}-61.54$ & 0.907 \\
\hline Unit energy inputs on crushing $E_{r}\left(J \cdot g^{-1}\right)$ & & $E_{r}=7.280 w_{z}+60.46$ & 0.948 \\
\hline $\begin{array}{l}\text { Index of susceptibility of seeds to crush- } \\
\text { ing } E_{f}\left(\mathrm{~J} \cdot \mathrm{m}^{-1}\right)\end{array}$ & 5500 & $\mathrm{E}_{\mathrm{f}}=0.791 \mathrm{w}_{\mathrm{z}}+2.550$ & 0.558 \\
\hline
\end{tabular}

\section{Conclusions}

Based on the research results one may formulate the following conclusions:

1. Moisture of lupine seeds more influences the process of impact crushing than the change of the rotational speed of hammer mills.

2. It was stated that along with the increase of the rotational speed, a reduction in the drop of the average dimension of particles of mill takes place.

3. Along with the increase of moisture of lupine from 8 to $14 \%$ a unit energy of crushing increases on average by approx. $83 \%$.

4. It was proved that the susceptibility ratio of seeds to crushing increases along with the increase of raw material moisture. Such relations were determined for all investigated rotational speeds of hammers. 


\section{References}

Andrejko, D., Grochowicz, J. (1999). Warunki wykorzystania nasion łubinu jako wysokobiałkowego surowca paszowego (cz.1). Pasze Przemystowe, 8. Warszawa.

Ball, M.E.E., Magowan E., McCracken, K.J., Beattie, V.E., Bradford, R., Thompson, A., Gordon, F.J. (2015). An investigation into the effect of dietary particle size and pelleting of diets for finishing pigs. Livestock Science, 173, 48-54.

Bartkiene, E., Pugajeva, I., Bartkevics, V., Zadeike, D., Juodeikiene, G. (2016). Reducing of acrylamide formation in wheat biscuits supplemented with flaxseed and lupine. LWT - Food Science and Technology, 65, 275-282.

Branland, G. (1997). La dureté des blés sélectionnés en France évolution et conséquences. Industries des Céréales 101, 5-10.

Bochat, A., Zastempowski, M. (2019). Wpływ konstrukcji rozdrabniacza bijakowego na skład granulometryczny rozdrabnianego materiału ziarnistego. Przemyst Chemiczny 98(9), 1499-1504.

Cruz-Chamorro, I., Álvarez-Sánchez, N., del CarmenMillán-Linares, M., del MarYust, M., Pedroche, J., Millán, F., Lardone, P.J., Carrera-Sánchez, C., MiguelGuerrero, J., Carrillo-Vico, A. (2019). Lupine protein hydrolysates decrease the inflammatory response and improve the oxidative status in human peripheral lymphocytes. Food Research International, 126.

Dziki, D. (2008). The crushing of wheat kernels and its consequence on the grinding process. Powder Technol. 185(2), 181-186.

Gimenoa, A., AlAlamia, A., Toralb, P.G., Frutosb, P., Abeciac, L., Fondevila, M., Castrillo, C. (2015). Effect of grinding or pelleting high grain maize-or barley-based concentrates on rumen environment and microbiota of beef cattle. Animal Feed Science and Technology, 203, 67-78.

Grochowicz, J., Andrejko, D. (1998). Obłuskiwanie nasion roślin strączkowych. Pasze Przemysłowe, 2.

Grudniewska, B. (1998). Hodowla i użytkowanie świń. Wyd. ART, Olsztyn.

Kalwaj, J. (2010). Zagadnienia energetyczne zespołu roboczego rozdrabniacza bijakowego do ziarna zbóż. Inżynieria i Aparatura Chemiczna, 5, 53-54.

Kulig, R., Laskowski, J. (2002). Określenie zależności między stopniem rozdrobnienia nasion roślin strączkowych a parametrami procesu granulowania. InżynieriaRolnicza, 7a, 155-163.

Lamp, A. E., Evans, A. M., Moritz, J. S. (2015). The effects of pelleting and glucanase supplementation in hulled barley based diets on feed manufacture, broiler performance, and digesta viscosity. J. Appl. Poult. Res., 2, 1-9.

Laskowski, J., Łysiak, G., (1999). Use of compression behaviour of legume seeds in view of impact grinding prediction. Powder Technol., 105, 83-88.

Laskowski, J., Łysiak, G., Skonecki, S. (2005). Mechanical properties of granular agro-materials and food powders for industrial practice. Part II. Material properties in grinding and agglomeration. Centre of Excellence for Applied Physics in Sustainable Agriculture AGROPHYSICS. Institute of Agrophysics PAS, Lublin, 159 ss.

López, E. P., Goldner, M. C. (2015). Influence of storage time for the acceptability of bread formulated with lupine protein isolate and added brea gum. LWT - Food Science and Technology, 64(2), 1171-1178.

Ma, X., Mason-Jones, K., Liu, Y., Blagodatskaya, E., Kuzyakov, Y., Guber, A., Dippold, M., Razavi, B. (2019). Coupling zymography with $\mathrm{pH}$ mapping reveals a shift in lupine phosphorus acquisition strategy driven by cluster roots. Soil Biology and Biochemistry, 135, 420-428.

Marks, N. (2010). Wpływ wilgotności na zużycie energii bezpośredniej w procesie rozdrabniania ziarna żyta i pszenżyta. Inżynieria Rolnicza, 7(125), 125-130.

Mayer-Laigle, C., Blanc, N., Rova, K., Rouau, X. (2018a). Comminution of Dry Lignocellulosic Biomass, a Review: Part I. From Fundamental Mechanisms to Milling Behaviour. Bioengineering, $5(2), 41$. 
Impact of moisture...

Mayer-Laigle, C., Rova, K., Blanc, N., Rouau, X. (2018b). Comminution of Dry Lignocellulosic Biomass: Part II. Technologies, Improvement of Milling Performances, and Security Issues. Bioengineering, 5(3), 334-358.

Olkowski, B. (2018). Feeding high lupine based diets for broiler chickens: Effect of soybean meal substitution with yellow lupine meal at various time points of growth cycle. Livestock Science, 218, 114-118.

Pabis, S., Jayas, D.S., Cenkowski, S. (1998). Grain Drying Theory and Practice. John Wiley and Sons, NewYork.

Posner, E. S. (1991). Wheat and flour ash as a measurement of millability. Cereal Food World, 36(8), 626-629.

PN-89/R-64798 - 1989. Pasze - oznaczanie stopnia rozdrobnienia.

PN-91/A-74010. Ziarno zbóż i przetwory zbożowe. Oznaczanie wilgotności.

Roszak, W., (1999). Technologie produkcji roślinnej. PWRiL, Warszawa. 78-139.

Wandersleben, T., Morales, E., Burgos-Díaz, C., Barahona, T., Labra, E., Rubilar, M., Salvo-Garrido, H., (2018). Enhancement of functional and nutritional properties of bread using a mix of natural ingredients from novel varieties of flaxseed and lupine. LWT - Food Science and Technology, 91 , 48-54.

Volek, Z., Bures, D., Uhlirova, L. (2018). Effect of dietary dehulled white lupine seed supplementation on the growth, carcass traits and chemical, physical, and sensory meat quality parameters of growing-fattening rabbits. Meat Science, 141, 50-56.

Zduńczyk, Z., Mikulski, B., Jankowski, B., Przybylska-Gornowicz, J., Juśkiewicz, A. (2019). Gastrointestinal response of laying hens to graded dietary inclusion levels of yellow lupine seeds. Animal Feed Science and Technology, 255, 112-124.

\section{WPLYW WILGOTNOŚCI I PRĘDKOŚCI BIJAKÓW NA EFEKTYWNOŚĆ ROZDRABNIANIA NASION ŁUBINU}

Streszczenie. Celem pracy było określenie oddziaływania wilgotności i prędkości obrotowej bijaków na proces rozdrabniania nasion łubinu. Surowiec doprowadzano do czterech poziomów wilgotności od 8 do $14 \%$ co $2 \%$. Badania przeprowadzono na laboratoryjnym rozdrabniaczu bijakowym, przy zastosowaniu zmiennych prędkość bijaków rozdrabniacza w przedziale 5500-7000 obr- $\mathrm{min}^{-1}$. Przeprowadzone badania wykazały, że występują istotne zależności $(\mathrm{p}<0,05)$ pomiędzy analizowanymi zmiennymi procesu a energochłonnością i podatnością nasion na rozdrabnianie.

Słowa kluczowe: łubin, rozdrabnianie, wilgotność, prędkość bijaków, rozdrabniacz bijakowy 